HORTICULTURAL ENGINEERING TECHNOLOGY FIXED EQUIPMENT AND BUILDINGS 


\section{Science in Horticulture Series}

General Editor: L. Broadbent, Emeritus Professor of Biology and Horticulture, University of Bath

Published in collaboration with the Royal Horticultural Society and the Horticultural Education Association.

This series of texts has been designed for students on courses in horticulture at the Higher Diploma or National Diploma level, but care has been taken to ensure that they are not too specialised for lower-level courses, nor too superficial for university work.

All the contributors to the series have had experience in the horticultural industry and/or education. Consequently, the books have a strong practical flavour which should reinforce their value as textbooks and also make them of interest to a wide audience, including growers and farmers, extension officers, research workers, workers in the agrochemical, marketing and allied industries, and the many gardeners who are interested in the science behind their hobby.

The authors are all British, but they have illustrated their books with examples drawn from many countries. As a result the texts should be of value to English-speaking students of horticulture throughout the world.

Other titles in the series are:

J. K. A. Bleasdale, Plant Physiology in Relation to Horticulture (Second Edition)

G. R. Dixon, Plant Pathogens and their Control in Horticulture

A. W. Flegmann and R. A. T. George, Soils and Other Growth Media

S. D. Holdsworth, The Preservation of Fruit and Vegetable Food Products

C. North, Plant Breeding and Genetics in Horticulture

M. J. Sargent, Economics in Horticulture

R. J. Stephens, Theory and Practice of Weed Control

E. J. Winter, Water, Soil and the Plant

and the companion volume to the present book

R. C. Balls, Horticultural Engineering Technology - Field Machinery 


\title{
HORTICULTURAL ENGINEERING TECHNOLOGY FIXED EQUIPMENT
AND BUILDINGS
}

\author{
R.C. BALLS \\ ANCAE \\ National Specialist Mechanisation Adviser with the Agricultural \\ Development and Advisory Service (ADAS) of the Ministry of \\ Agriculture, Fisheries and Food, U.K.
}

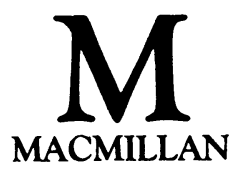


ㄷ R. C. Balls 1986

All rights reserved. No reproduction, copy or transmission of this publication may be made without written permission.

No paragraph of this publication may be reproduced, copied or transmitted save with written permission or in accordance with the provisions of the Copyright Act 1956 (as amended).

Any person who does any unauthorised act in relation to this publication may be liable to criminal prosecution and civil claims for damages.

First published 1986

Published by MACMILLAN EDUCATION LTD

Houndmills, Basingstoke, Hampshire RG21 2XS

and London

Companies and representatives

throughout the world

Typeset by

TecSet Ltd, Sutton, Surrey

British Library Cataloguing in Publication Data Balls, R. C.

Horticultural engineering technology: fixed equipment and buildings.

1. Horticultural machinery

I. Title

$635^{\prime} .028 \quad 5678.7$ 


\section{CONTENTS}

Preface $\quad x i$

Acknowledgements xii

1 PACKHOUSE DESIGN AND OPERATION 1

1.1 Reception 1

1.1.1 Weighing 1

1.1.2 Weather protection 2

1.1.3 Conditioning during holding 2

1.1.4 Cold chain reception 2

1.1.5 Emptied container storage 3

1.2 Intake 3

1.2.1 Hand feed 3

1.2.2 Bulk bin emptying 3

1.2.3 Trailer emptying 6

1.2.4 Flotation 6

1.2.5 Conveyor discharge trailers $\quad 7$

1.2.6 Tipper trailer control $\quad 7$

$\begin{array}{lll}1.3 \text { Cleaning } & 7\end{array}$

1.3.1 Dry loose soil $\quad 7$

1.3.2 Light trash removal 9

1.3.3 Washing 9

1.3.4 Automatic separating methods 13

1.4 Quality grading 14

1.4.1 Mechanical sorting $\quad 14$

$\begin{array}{ll}\text { 1.4.2 Manual sorting } & 14\end{array}$

$\begin{array}{lll}1.5 & \text { Size grading } & 18\end{array}$

1.5.1 Definition of size grades 18

$\begin{array}{ll}\text { 1.5.2 Size grading methods } & 19\end{array}$

1.5.3 Weight grading 28

$\begin{array}{ll}1.6 & \text { Preparation for market } \\ & 30\end{array}$

1.6.1 Onion topping 30

1.6.2 Radish topping 31

1.6.3 Bulb cleaning 31

1.6.4 Leek and celery trimming 32 
1.6.5 Sprout trimming 32

1.6.6 Apple polishing 33

1.7 Weighing and packing 33

1.7.1 Bulk packs 33

1.7.2 Pre-packing 35

1.7.3 Counters 38

$\begin{array}{ll}\text { 1.7.4 Wrapping } & 39\end{array}$

1.7.5 Bundle tying $\quad 40$

1.7.6 Carton and bag sealing 41

1.7.7 Weight/price ticketing 42

1.8 Packhouse layout and design 42

1.8.1 Materials handling 42

1.8.2 Produce flow for manual operations 46

1.8.3 Environmental factors 47

1.8.4 Workplace layout $\quad 48$

2 GLASSHOUSES \& TRANSLUCENT PLASTIC STRUCTURES 50

2.1 Construction 50

2.1.1 Glasshouses $\quad 50$

2.1.2 Tunnels 52

2.2 Light transmission characteristics 53

2.3 Solar heating effect 55

2.4 Heat loss reduction 55

2.4.1 Cladding systems $\quad 56$

2.4.2 Thermal screens $\quad 57$

2.4.3 Partially opaque structures $\quad 59$

3 BUILDINGS 60

3.1 Structures for storage of crops in bulk 60

3.1.1 Calculation of thrust wall forces 61

3.1.2 Construction of thrust walls 61

3.2 Insulation 65

3.2.1 Theory of insulation 65

3.2.2 Insulation materials 68

3.2.3 The effects of water on insulation 70

3.2.4 Fire resistance $\quad 71$

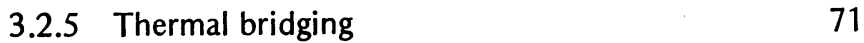

$\begin{array}{ll}3.3 & \text { Air leakage } \\ & 72\end{array}$

3.3.1 Definitions and values 72

3.3.2 Methods of reducing air leakage 73

3.4 Controlled atmosphere (CA) storage $\quad 74$

3.4.1 Methods of sealing $\quad 74$

3.4.2 Store testing 75

3.4.3 Leak detection $\quad 75$ 
3.5 Building applications $\quad 75$

3.5.1 Crop storage $\quad 75$

3.5.2 Mushroom and rhubarb sheds $\quad 78$

$\begin{array}{lll}\text { 3.5.3 Packhouses } & 79\end{array}$

4 FUELS AND HEAT PRODUCTION

4.1 Fuels $\quad 80$

4.1.1 Calorific value 80

4.1.2 Characteristics of fuels 81

4.1.3 Fuel storage $\quad 86$

4.2 Combustion principles $\quad 88$

4.2.1 Basic chemical reaction 88

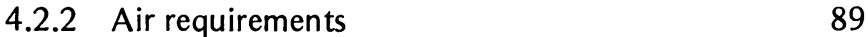

4.2.3 Combustion air measurement $\quad 89$

4.2.4 Efficiency and flue loss 90

4.2.5 Fuel contaminants 91

4.2.6 Smut emission 92

$\begin{array}{ll}\text { 4.2.7 Turndown ratio } & 92\end{array}$

4.3 Combustion equipment 92

4.3.1 Solid fuel 92

4.3.2 Oil fuel burners 96

4.3.3 Gaseous fuel burners 101

4.3.4 Factors affecting choice of fuel 103

4.4 Chimneys and flues 106

4.4.1 Size requirements 106

4.4.2 Construction and installation 108

4.5 Air heaters 109

4.5.1 Direct firing 109

4.5.2 Indirect heater 110

$\begin{array}{ll}\text { 4.5.3 Electric heating } & 112\end{array}$

$\begin{array}{lll}4.6 & \text { Boilers } & 113\end{array}$

4.6.1 Types of boiler 113

4.6.2 Working pressure $\quad 117$

4.6.3 Feed water quality and treatment 118

4.6.4 Water feed to steam boilers 120

$\begin{array}{ll}\text { 4.6.5 Low-temperature corrosion } & 120\end{array}$

4.6.6 Feed and expansion connections $\quad 121$

4.6.7 Boiler temperature control 122

5 HEAT DISTRIBUTION 123

5.1 Basic layout considerations 123

5.1.1 Heat input requirements 123

5.1.2 Temperature distribution 123

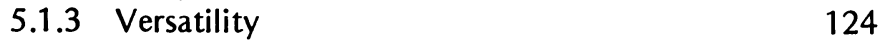

$\begin{array}{ll}5.1 .4 & \text { Reliability } \\ & 124\end{array}$ 
$\begin{array}{lll}5.2 \text { Warm air } & 125\end{array}$

5.2.1 Free air blowing 125

5.2.2 Ducted warm air $\quad 125$

5.3 Piped hot water 126

5.3.1 Pipe for air heating 126

5.3.2 Heat emission 127

$\begin{array}{ll}\text { 5.3.3 Pipe layout } & 129\end{array}$

5.3.4 Water circulation 130

5.3.5 Steam/hot water conversion 131

5.3.6 Pressurised hot water 131

5.4 Steam 133

5.4.1 Live steam heating 133

5.4.2 Steam characteristics 134

$\begin{array}{ll}\text { 5.4.3 Pipework sizing } & 135\end{array}$

5.4.4 Steam traps 135

5.4.5 Other steam fittings 138

5.4.6 Condensate return 138

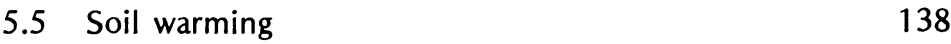

5.5.1 Soil warming system design 138

$\begin{array}{ll}\text { 5.5.2 Electric systems } & 139\end{array}$

5.5.3 Hot water systems 139

5.6 Mains and ancillaries 140

5.6.1 Insulation 140

5.6.2 Thermal expansion 141

5.7 System control 142

5.7.1 Warm air 142

$\begin{array}{ll}\text { 5.7.2 Hot water } & 142\end{array}$

5.7.3 Steam systems $\quad 144$

5.8 Heating system design 144

5.8.1 Heat loss from the structure 144

5.8.2 Heating or boiler rating 146

5.8.3 Heating pipework 146

5.8.4 Pump requirements 148

5.8.5 Warm air ducts 150

5.8.6 Predicting fuel consumption 151

6 EQUIPMENT FOR PROTECTED CROP STRUCTURES 153

6.1 Ventilation 153

6.1.1 Natural ventilation 153

6.1.2 Powered ventilation 156

6.2 Sterilisation of soils and composts 159

6.2.1 Batch treatment 159

6.2.2 Continuous flow treatment 159

6.2.3 In situ treatment 159

6.2.4 Mushroom compost 161 
6.3 Carbon dioxide enrichment 162

6.3.1 Methods of $\mathrm{CO}_{2}$ enrichment 163

6.3.2 Quantity of gas 164

6.3.3 Control and monitoring 164

6.4 Irrigation 165

6.4.1 Overhead systems 165

6.4.2 Low-level systems 167

6.4.3 Nutrient film technique (NFT) 169

6.4.4 Adding nutrients to irrigation systems $\quad 170$

6.4.5 Water supply 172

$\begin{array}{ll}6.5 & \text { Lighting } \\ & 173\end{array}$

6.5.1 Light requirements 173

6.5.2 Lamp type 175

$\begin{array}{ll}\text { 6.5.3 Installation } & 177\end{array}$

7 EQUIPMENT AND SYSTEMS FOR CROP STORAGE 182

$\begin{array}{lll}7.1 & \text { Crop drying } & 182\end{array}$

$\begin{array}{lll}\text { 7.1.1 Root crop drying } & 182\end{array}$

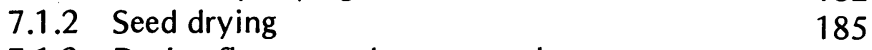

7.1.3 Drying flowers and ornamentals 187

$\begin{array}{lll}7.2 & \text { Crop storage methods } & 187\end{array}$

$\begin{array}{ll}\text { 7.2.1 Crop requirements } & 187\end{array}$

7.2.2 Ambient air cooling $\quad 190$

7.2.3 Refrigerated cooling 191

7.2.4 Calculation of cool store refrigeration capacity 193

$\begin{array}{ll}7.3 \text { Rapid cooling systems } & 196\end{array}$

7.3.1 Conventional, direct expansion stores 196

7.3.2 Wet air cooling 196

$\begin{array}{ll}\text { 7.3.3 Hydrocooling } & 199\end{array}$

$\begin{array}{ll}\text { 7.3.4 Vacuum cooling } & 199\end{array}$

$\begin{array}{ll}\text { 7.3.5 Cryogenic cooling } 200 & 200\end{array}$

7.3.6 Calculation of rapid cooling plant capacity 201

$\begin{array}{ll}7.4 \text { Air distribution and circulation } & 202\end{array}$

$\begin{array}{lll}\text { 7.4.1 Bulk stores } & 202\end{array}$

7.4.2 Box, pallet and tray store ventilation systems 206

7.4.3 Introducing cooling into stores 213

$\begin{array}{ll}\text { 7.4.4 Air-handling units } & 215\end{array}$

$\begin{array}{ll}7.5 \text { Fans } & 216\end{array}$

7.5.1 Types of fan 216

7.5.2 Fan laws and theory 222

7.5.3 Fan selection 223

7.5.4 Fan installation 225

$\begin{array}{ll}7.6 \text { Refrigeration } & 227\end{array}$

7.6.1 Components that form the basic refrigeration cycle 
7.6.2 Other components of the refrigeration system 228

7.6.3 Refrigerants

7.6.4 Coefficient of performance (COP) 231

7.6.5 Component selection 231

7.7 Heaters

232

7.8 Humidity

232

7.8.1 Psychrometry

232

7.8.2 Humidification equipment

233

7.8.3 Dehumidification equipment

236

7.9 Atmosphere control

237

7.9.1 Oxygen and $\mathrm{CO}_{2}$

237

7.9.2 Ethylene control

238

Appendix A: Metric conversion factors

239

Appendix B: Further reading

242

Index

244 


\section{PREFACE}

I have often felt that 'horticultural engineering' lies uneasily between the horticultural sciences and pure engineering. The horticulturist or plant scientist often finds engineering principles difficult to grasp, while the pure engineer usually lacks the practical knowledge of plant behaviour or requirements.

The modern horticulturist is heavily reliant on engineering by way of mechanisation at all stages from establishment to marketing. A working knowledge of engineering will help in three ways: awareness of what is available, ability to specify requirements in broad terms and improved efficiency of operating equipment.

In writing this book I have tried to establish the basic engineering principles of which the modern horticulturist must be aware, and to describe the equipment that is likely to be encountered. It is also hoped that students or practitioners of engineering will be able to grasp the basic applications requirements of the horticultural industry.

Obviously, as the book has to cover such a wide range of engineering sciences, some cannot be explored in great depth, and consequently the reader will have to continue by way of the books cited in the bibliography. Attention is also drawn to the companion volume: Horticultural Engineering Technology - Field Machinery. In line with the majority of the engineering industry, the two books are written entirely in SI (Systeme International) metric units; conversions to Imperial and other common units will be found in appendix A.

Houghton Conquest

R. C. BALLS

Bedford 


\section{ACKNOWLEDGEMENTS}

I would like to acknowledge the help given by colleagues in the Advisory Services and Research Stations, and also the information supplied by equipment manufacturers. The following companies and organisations have kindly allowed their drawings to be copied: CIBSE, London (figure 7.19); The Electricity Council, London (figures 6.5 and 6.6); Hamworthy Engineering Ltd, Poole (figure 4.3(b)); Spirax-Sarco Ltd, Cheltenham (figure 5.3(a)-(d)); and Woods of Colchester Ltd (figures 7.14, 7.15 and 7.17).

Full use has been made of my experience gained during advisory work on horticultural holdings throughout Britain, and I am grateful for the permission to draw on this work given by my senior officers in ADAS. Finally I am indebted to my wife for typing the manuscript. 